\title{
シンポジウム 如何にすれば患者の一生を通じて咀嚼
}

\section{能力を維持出来るか}

\author{
河辺清治
}

臨床家は，現在進歩しつつある歯学を正しく批判しな がらよりよい明日への人類の幸福を目指さなければな らない。ところが今日の歯学のあり方はあまりにも分科 され，口腔単位の総合的な雬科医院を忘れているのでは ないかと心配するものである。

とくに，歯の疾患は実質欠損をともなうので，今日ま で歯学は如何にしてての実質欠損を予防するかに最大の 努力が注れたが，現在のとてろてれを零に導くまでには 至っていない。

しかし，硬組織疾患に対しては，予防菌科学的に蔽を 保存するととは可能であるが，歯周疾患に対しては局所 療法に始まり，今日では咬、合論の立場より努力が行なわ れ，かなり良い結果をあげるようになったが，歯周組織 には組織の老化も加わり，いろいろ問題点が残されてい る。

表 1 日本人の平均寿命

\begin{tabular}{c|c|c}
\hline & 男 & 女 \\
\hline 昭和10 11 & 46.92 & 49.63 \\
22 & 50.06 & 53.96 \\
$25 \sim 27$ & 59.57 & 62.97 \\
30 & 63.90 & 67.75 \\
35 & 65.32 & 70.19 \\
36 & 66.03 & 70.79 \\
37 & 66.23 & 71.16 \\
38 & 67.21 & 72.34 \\
39 & 67.67 & 72.87 \\
40 & 67.73 & 72.95 \\
41 & 68.35 & 73.61 \\
\hline
\end{tabular}

表 2 月本人の 1 人平均鼛失歯数

\begin{tabular}{|c|c|}
\hline & 1 人平均吉失歯数 \\
\hline 50 才台 & 12.96本 \\
\hline 60 才 台 & 18.20 \\
\hline 70 才台 & 22.14 \\
\hline 80 才台 & 22.63 \\
\hline
\end{tabular}

表 3

\begin{tabular}{lr}
\hline 発育期 & $0 \sim 24$ 才 \\
成熟 期 & $25 \sim 45$ 才 \\
過 縮 期 & $46 \sim$ 以上 \\
\hline
\end{tabular}

表 4

\begin{tabular}{ll}
\hline 初老者 & $46 \sim 55 才$ \\
老年 者 & $56 \sim 35 才$ \\
長 寿 者 & $66 \sim$ 以上 (照和) \\
\hline
\end{tabular}

一方日本人の平均寿命は, 表 1 のうに戦後急速にの び，約 20 年間， 50 才 70 才となり，近年高年令の人口が ふえ, 昭和 42 年の厚生省白書に依ると, 現在 65 才以上は $6.5 \%$ であるが昭和 70 年には $12.8 \%$ になると推計されて いる。

また, 日本人の欠損歯数は厚生省の統計に依ると, 表 2 のように，50才台では約13本で10才を経るにしたが い，5本の菌が失なわれている。そしててれまで欠損歯 数が多くなると補緅法としては, 有床義歯にたよる症例 が多くなり，有床義歯を有効に活用するには，歯槽骨に 良い条件が必要となってくる。乙てにおいて補経学の立 場から考えれば，組織学的に歯槽骨の保護が強くのぞま れる。

一般病理組織学的には, 表 3 のように45才をてえると 退縮期に入る。また, 緒方知三郎の耳下腺ホルモン学に 依れば表 4 のように45才をてえると老年期に入ると云わ れるが，ただし人間には個人差があって $5 \sim 10$ 年の差の あるととは云うまでもない。

この耳下腺ホルモンは, 人間の間葉性組織の発育を促 すもので, 歯周疾患の治療に用いれば, ある程度効果が あると云われている。

このような骨組織の発育を促す化学物質が失なわれて から抜歯すると, 抜歯創の治癒機転が活発に行なわれず 歯槽骨は吸収し，良い条件の歯槽骨が得られなくなる。

てのほか整形外科に，骨折の場合に何才位から治痖が 遅くなるかをしらべて見た処，やはり“40才の半ばを境 として治癒が遅れ，そして面白いととには，高年令にな るにしたがい，次第に弱い骨組織で修復されると云う。

組織学的には, 骨組織は高令に至るにしたがい多孔性 構造となり，骨髄腔は拡大し，脂肪髄となって来る。て のように補綴臨床においても高令で抜歯されたばあい, 


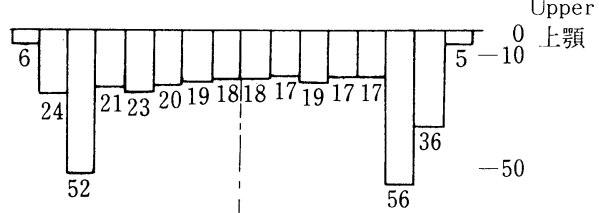

300

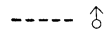

우
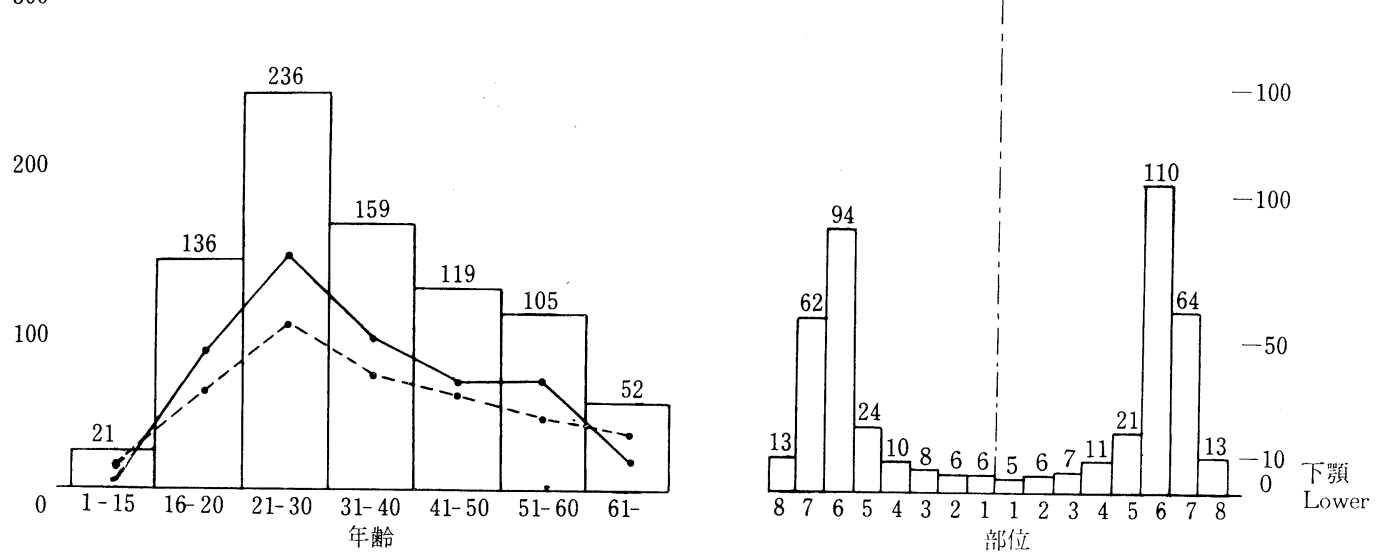

図 1 う玲による拔蒌数

숭 235 , 우 255 (人)

$500-$

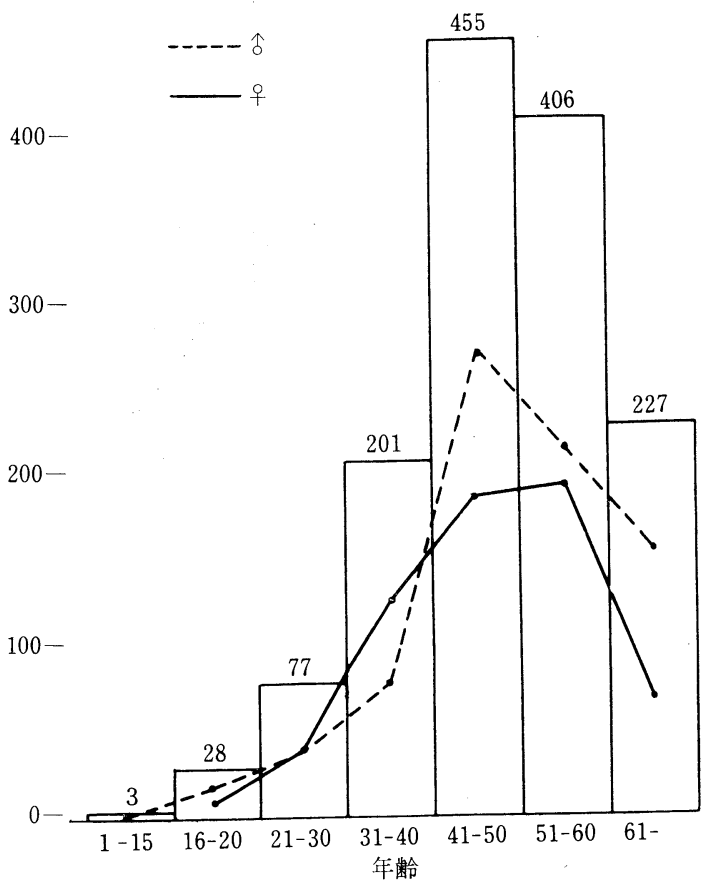

図 2 歯周疾患に上る抜㐘数

今 241 , 우 164 (人)
合 368 , 우 460 (歯)
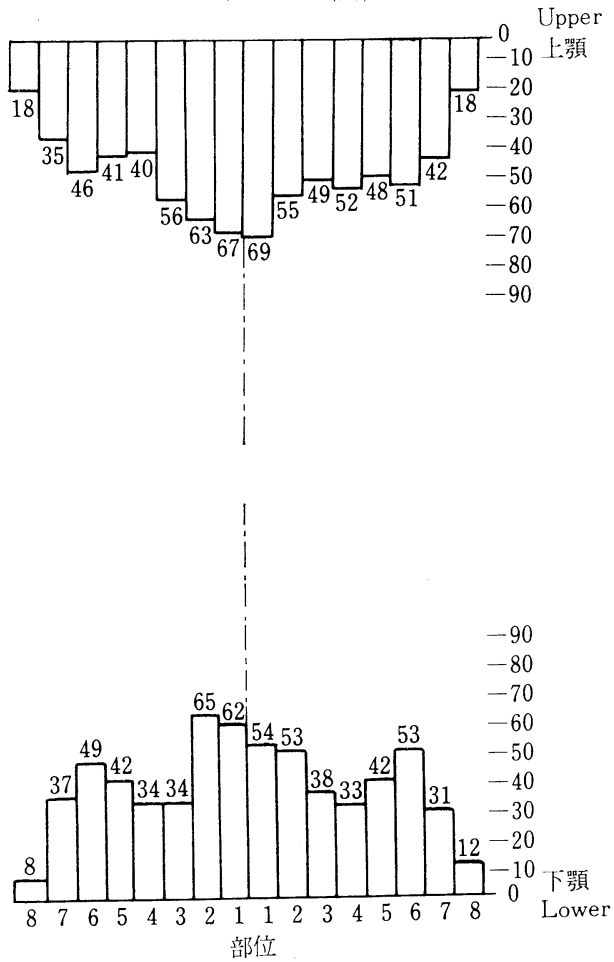

令 779 , 우 618 (歯) 
橉槽骨は弱い骨構造となり，咀嚼压を十分負担するとと が出来ず難症例となり，高令に至り勗嚼機能の抵下はま ぬがれない。

それでは一般臨床においてどのように歯が失なわれて いくかを臨床統計に依りしらべて見るととにする。との 統計は昭和 $20 \sim 24$ 年の 4 年間に東歯大外科における抜歯 率を病因別に分類したもののうち硬組織疾患と歯周疾患 によるものを年令，部位，別に取り上げたものである。 ウ蝕に依る抜歯率図 1 によれば20才台が最高で, 部位 別には第 1 大臼歯が最高率を示し, しかも下顎の第 1 大 臼歯が最高で，次に第 2 大曰歯が失なわれ，下顎に遊離 端欠損が若い年令に生ずることが明らかにされた。下顎 に遊離端欠損が片側性に生ずると, 咀嚼時の側方運動に 対する咬合均衡が破れ, 有歯側の均衡側, 上顎舌側咬頭
内斜面に初期接触が起り, 雨周疾患の原因となるので, 咬合調整の必要が高まる。そして久損が進み阿側性の遊 離端欠損となると，前菌部に負担が加わる。

一方歯周疾患による抜歯率図 2 によれば40才台に向い 急速に抜歯率が高まり，部位別には上顎前曾部が最高を 示している。

そして, 有床義歯で補経された場合, 歯根膜負担の有 歯部と粘膜負担の補緅部との咬合均衡が取りにくく, 残 存歯に負担が加わる。

以上のように高令人口が増しつつある今日, 患者の一 生を通じて咀嚼能力の抵下を予防するには，あまり一方 的に雬周疾患に対する局所療法にとらわれず，患者の年 令に対する組織力を考えながら, 抜歯の時期を決定し瞇 槽骨の保護を考えるべきでは無いかと思う。 